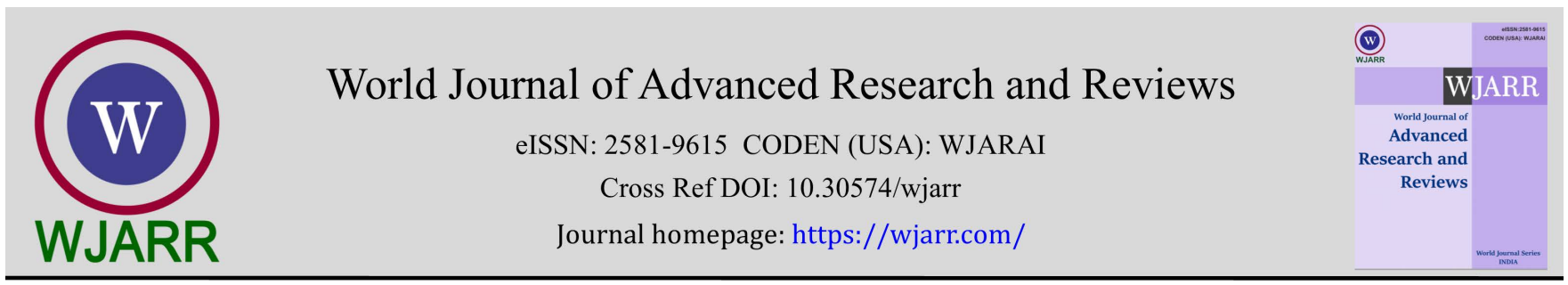

(RESEARCH ARTiClE)

\title{
Effect of spatial arrangement and cropping systems on the productivity of cassava- legume intercropping systems in three Agro-climatic zones of Sierra Leone
}

\author{
Augustine Mansaray ${ }^{1,}{ }^{*}$, Abdul Babatunde Karim ${ }^{2}$, Thomas BR Yormah ${ }^{2}$ and Abdul Rahman Conteh ${ }^{1}$ \\ ${ }^{1}$ Natural Resource Management, Njala Agricultural Research Center (NARC), Sierra Leone. \\ ${ }^{2}$ Fourah Bay College, University of Sierra Leone, Sierra Leone.
}

World Journal of Advanced Research and Reviews, 2022, 13(03), 025-034

Publication history: Received on 19 January 2022; revised on 27 February 2022; accepted on 01 March 2022

Article DOI: https://doi.org/10.30574/wjarr.2022.13.3.0172

\begin{abstract}
Competition is one of the most important factors that influence productivity of component crops in intercropping systems. Thus, an experiment was conducted in order to evaluate the competitive interactions between the component crops in a cassava-legume based intercropping system. The experiment was a factorial randomized complete block design with three replications. The treatments consisted of seven cropping associations and two spatial arrangements. The results show that the root yield for cassava was higher for the cassava-soybean system with Segbwema recording the highest root yield. For the grain legumes, yields were higher for the sole legumes compared to the intercropped. In addition, both root and grain yields were on average higher when the grain legumes were intercropped with cassava using the $2 \mathrm{~m} \times 0.5 \mathrm{~m}$ spatial arrangement for cassava.

The result further shows that land equivalent ratio was greater than one and was higher for the cassava-soybean system compared to the other cropping systems. Furthermore, the result shows a higher monetary advantage index for all cropping systems indicating that all cropping systems were feasible and profitable. In conclusion, it was shown that cassava-legume intercropping systems were more advantageous in terms of productivity and monetary advantage for smallholder farmers across the three agro-climatic zones.
\end{abstract}

Keywords: Competition; Cropping system; Land equivalent ratio; Monetary advantage index; Productivity; Agroclimatic zone

\section{Introduction}

Intercropping is one of the sustainable agricultural methods defined as the growing of two or more crops on the same piece of land within the same year to promote their interactions. According to Hauggaard-Nielsen et al [1] and Chapagain et al [2], this type of cropping system results in the improvement of crop productivity, provides good land cover to protect soil from water and wind erosion, improves soil organic matter and soil fertility through nitrogen fixation and increases employment opportunities.

Cassava (Manihot esculenta Crantz) is an annual crop grown widely in the tropics as food and as cash crop. Cassavabased cropping systems are common as cassava is one of the major staple foods grown in most sub-Saharan African countries [3]. It is the second most important staple food in Africa after maize, in terms of calories consumed. In Sierra Leone, cassava is the second staple after rice. Cassava intercropping is commonly practiced among small-scale farmers in the humid and sub-humid tropics. According to [4], about 50\% of cassava grown in tropical Africa is intercropped with cereals, grain legumes, leafy vegetables, fruits and tree crops. Intercropping of cassava with grain legumes has been popular in tropical environments [5; 6] because legumes have the potential of biological nitrogen fixation, which may

${ }^{*}$ Corresponding author: Augustine Mansaray

Natural Resource Management, Njala Agricultural Research Center (NARC), Sierra Leone.

Copyright (C) 2022 Author(s) retain the copyright of this article. This article is published under the terms of the Creative Commons Attribution Liscense 4.0. 
be an important factor in conserving soil nitrogen. In addition, according to Mutsaers et al [7], cassava-grain legume intercropping systems can increase land equivalent ratio as compared to the pure stand. For instance, intercropping cassava with groundnut increases the productivity by land equivalent ratio of 1.27 to 1.85 [8].

Several factors can affect the growth and productivity of the species in intercropping particularly planting ratio, spatial arrangement, plant density, cropping system and competition [9; 10;11]. Willey [12] reported that higher performance in intercropping systems could be achieved when interspecific competition between intercropping components is lower than intraspecific competition. Grain legumes such as groundnut, cowpea and soybean are short duration crop that matures at around 70-120 days, which could be fitted well in a cassava-legume based intercropping system. However, it is necessary to determine the optimum population of the grain legumes as a companion crop to minimize competition with the main cassava crop. This experiment was therefore, undertaken to determine the appropriate spatial arrangement of cassava and cropping system in order to achieve maximum productivity and economic return from cassava-legume based intercropping system.

\section{Material and methods}

\subsection{Study Area}

The study was carried out between 2015-2017 in three agro-climatic zones namely Sumbuya representing the transitional rain forest, Makeni representing the savannah woodland and Segbwema representing the rain forest zone.

\subsection{Plant Material}

All plant materials were obtained from Njala Agricultural Research Center, Njala. The cassava variety used was slicass 6, which is the erect type. The varieties of the grain legume were Slipea 5 (cowpea), Slibean 2 (Soybean) and Slinut 1 (groundnut).

\subsection{Experimental design and treatment}

The experiment was a factorial randomized complete block design with three replications. The treatments consisted of seven cropping associations (sole cassava, sole groundnut, sole cowpea, sole soybean, cassava + cowpea, cassava + groundnut and cassava + soybean) and two spatial arrangements of cassava ( $1 \mathrm{~m} \times 1 \mathrm{~m}$ and $2 \mathrm{~m} \times 0.5 \mathrm{~m})$. The plot size was $7 \mathrm{~m} \times 6 \mathrm{~m}$.

Cassava was planted at the spacing's of $1 \mathrm{~m}$ x $1 \mathrm{~m}$ (1: 1) and $2 \mathrm{~m}$ x $0.5 \mathrm{~m}$ (1: 3) respectively; whilst cowpea and groundnut were planted at the spacing of $50 \mathrm{~cm} \times 20 \mathrm{~cm}$ with two seeds per hole for cowpea and one seed per hole for groundnut. On the other hand, soybean was planted at the spacing of $50 \mathrm{~cm} \times 10 \mathrm{~cm}$ with two seeds per hole. The legumes were introduced in between the rows of the cassava. Weeding was done with hoe at one, three and six months after planting. Cassava was harvested at 12 months after planting whilst the three legumes were harvested at their different maturity dates.

\subsection{Data collection}

Yield data for both the cassava and the three grain legumes were collected at harvest from the net plot. Root yield was determined by harvesting all the cassava plants within the net plot followed by detachment of all the storage roots from the stump and weighing using a salter scale. Root yield was expressed in $\mathrm{t} / \mathrm{ha}$.

For the three grain legumes, the matured dried pods were harvested from the net plot. The grains were weighed on a sensitive balance and the weights obtain was then extrapolated to $\mathrm{Kg} / \mathrm{ha}$.

The productivity of cassava-legume based intercropping system was assessed using land equivalent ratio (LER) and monetary advantage index (MAI) by using the standard formulae. The land equivalent ratio was calculated according to [13] as follows:

$$
\begin{gathered}
\mathrm{LER}=\{\mathrm{La}+\mathrm{Lb}\} \\
\mathrm{La}=(\mathrm{Yab} / \mathrm{Yaa}) \\
\mathrm{Lb}=(\mathrm{Yba} / \mathrm{Ybb})[14]
\end{gathered}
$$


Where La and Lb are the land equivalent ratios for the individual crops, Yab and Yba are the individual crop yields in intercropping and Yaa and Ybb are the individual crop yields in sole cropping.

Monetary advantage index was calculated according to [14] as

$$
\text { MAI }=\frac{\text { (value of combined intercrops) }}{\text { LER }} \times(\text { LER }-1)
$$

\subsection{Data Analysis}

Data on yield parameter of main and component crops were recorded using standard procedures and analyzed statistically using SAS statistical package on a computer. The differences among treatment means were separated using the Student Newman-Keuls Test (SNK) at 0.05 level of significance [15].

\section{Results}

\subsection{Root and grain yield}

Root yield varies significantly $(\mathrm{P}<0.05)$ among cropping system with respect to agro-climatic zones with cassavasoybean system recording the highest root yield across the three zones (Table 1). At Makeni, significant differences (P $<0.05$ ) were observed in root yield among cropping systems with cassava-soybean system (15.23) recording the highest followed by cassava-groundnut (15.04), sole cassava (12.69) whilst cassava-cowpea system (11.01) recorded the least. There were however no significant differences $(\mathrm{P}<0.05)$ in root yield among cassava-soybean, cassava-groundnut and sole cassava (Table 1). The root yield ranged from 11.01-15.23. Root yield was generally lower in Makeni compared to the other two zones. Similarly, significant differences $(\mathrm{P}<0.05)$ were observed in root yield among cropping system at Segbwema.

Table 1 Root and grain yield of component crops as influenced by cropping system

\begin{tabular}{|l|c|c|c|c|c|c|}
\hline \multirow{2}{*}{ Treatments } & \multicolumn{3}{|c|}{ Root yield (t/ha) } & \multicolumn{3}{c|}{ Grain yield (Kg/ha) } \\
\cline { 2 - 8 } & \multicolumn{3}{|c|}{ Agro-climatic zone } & \multicolumn{3}{c|}{ Agro-climatic zone } \\
\cline { 2 - 8 } & Makeni & Segbwema & Sumbuya & Makeni & Segbwema & Sumbuya \\
\hline Cassava-groundnut & $15.04 \mathrm{a}$ & $21.50 \mathrm{~b}$ & $16.04 \mathrm{~b}$ & 512.93 & 519.39 & 512.01 \\
\hline Cassava-cowpea & $11.01 \mathrm{~b}$ & $20.97 \mathrm{~b}$ & $11.98 \mathrm{c}$ & 684.84 & $1,103.30$ & 403.24 \\
\hline Cassava-soybean & $15.23 \mathrm{a}$ & $30.89 \mathrm{a}$ & $20.60 \mathrm{a}$ & 839.91 & $1,287.55$ & 685.85 \\
\hline Sole cassava & $12.691 \mathrm{ab}$ & $27.07 \mathrm{ab}$ & $17.02 \mathrm{~b}$ & - & - & - \\
\hline Sole groundnut & - & - & - & 528.29 & 674.35 & 801.84 \\
\hline Sole cowpea & - & - & - & 946.22 & $1,540.56$ & 417.02 \\
\hline Sole soybean & - & - & - & 956.89 & $1,430.55$ & 964.80 \\
\hline
\end{tabular}

Means in column with the same letter are not significantly different at $\mathrm{P}>0.05$ (SNK)

As in Makeni, the cassava-soybean system (30.89) again recorded the highest root yield followed by the sole cassava (27.07), cassava-groundnut (21.50) and the cassava-cowpea system (20.07) (Table 1). There were however no significant differences $(\mathrm{P}>0.05$ ) in root yield between cassava-soybean and sole cassava and between cassava-cowpea and cassava-groundnut systems. Root yield was generally higher in Segbwema compared to the other two zones.

In addition, for Sumbuya, root yield varies significantly $(\mathrm{P}<0.05)$ among cropping systems; however there were no significant differences $(\mathrm{P}>0.05)$ in root yield between the sole cassava and the cassava-groundnut system. The root yield in Sumbuya ranged from 11.98-20.60 (Table 1). Generally, root yields were consistently higher with the cassavasoybean cropping system compared to the sole cassava. In addition, at Makeni the yield for the cassava-groundnut system was higher than the sole cassava (Table 1), 
For the grain legumes, yields were generally higher in the sole system compared to intercropped system. The yields generally ranged from 512.01-519.39, 403.29-684.84 and 685.85-1,287.55 for cassava-groundnut, cassava-cowpea and cassava-soybean systems respectively across the agro-climatic zones (Table 1). The yields for the three legumes were on average higher in Segbwema compared to the other two zones.

Concerning spatial arrangement, root yields were on average generally higher for the $2 \mathrm{~m} \times 0.5 \mathrm{~m}$ spatial arrangement compared to the $1 \mathrm{~m} \times 1 \mathrm{~m}$ arrangement (Table 2). In addition, irrespective of spatial arrangement, the cassava- soybean system was observed to have recorded the highest root yield compared to the other systems. For the grain legumes also, yields were on average higher for the $2 \mathrm{~m} \times 0.5 \mathrm{~m}$ spatial arrangement for cassava compared to the $1 \mathrm{~m} \times 1 \mathrm{~m}$ arrangement (Table 2). In general, irrespective of spatial arrangement, yields for the three legumes were higher in the sole cropping system compared to the intercropping system.

Table 2 Root and grain yield of component crops as influenced by spatial arrangement of cassava

\begin{tabular}{|l|c|c|c|c|c|c|}
\hline \multirow{2}{*}{ Treatments } & \multicolumn{3}{|c|}{ Root yield (t/ha) } & \multicolumn{3}{c|}{ Grain yield ( Kg/ha) } \\
\cline { 2 - 6 } & \multicolumn{3}{|c|}{ Agro-climatic zone } & \multicolumn{3}{c|}{ Agro-climatic zone } \\
\cline { 2 - 7 } & Makeni & Segbwema & Sumbuya & Makeni & Segbwema & Sumbuya \\
\hline Cassava-groundnut 1: 1 (1 m x 1 m) & 10.48 & 28.00 & 12.81 & 426.23 & 362.04 & 414.09 \\
\hline $\begin{array}{l}\text { Cassava-groundnut 1: } \\
\text { m) }(2 \mathrm{~m} \text { x 0.5 }\end{array}$ & 16.66 & 30.22 & 18.16 & 557.98 & 427.24 & 527.31 \\
\hline Cassava-cowpea 1: 1 (1 m x 1 m) & 10.39 & 27.17 & 10.61 & 808.00 & $1,610.24$ & 744.33 \\
\hline Cassava-cowpea 1: 3 (2 m x 0.5 m) & 13.62 & 28.50 & 10.11 & $1,244.72$ & $2,045.61$ & 837.27 \\
\hline Cassava-soybean 1: 1 (1 m x 1 m) & 19.42 & 47.90 & 27.56 & 885.81 & 788.44 & 801.92 \\
\hline Cassava-soybean 1: 3 (2 m x 0.5 m) & 22.91 & 34.16 & 24.72 & 890.67 & 809.15 & 824.68 \\
\hline Sole cassava & 13.77 & 35.06 & 17.55 & - & - & - \\
\hline Sole groundnut & - & - & - & 605.60 & 578.12 & 590.00 \\
\hline Sole cowpea & & & & $1,542.65$ & $2,743.48$ & $1,344.78$ \\
\hline Sole soybean & & & $1,321.27$ & $1,045.24$ & $1,002.02$ \\
\hline
\end{tabular}

\subsection{Competitive and economic functions of cassava and component crops}

\subsubsection{Land equivalent ratio}

The partial land equivalent ratio with respect to cropping system for both cassava and the legumes were above 0.5 across all zones (Table 3). In addition, the partial land equivalent ratio for cassava was higher than the legumes for all cropping systems except for cassava-cowpea system at Sumbuya where the partial land equivalent ratio for cowpea was higher than cassava. The total land equivalent ratios across zones were not significantly different $(\mathrm{P}>0.05)$ although higher value was recorded in Makeni (1.98) followed by Segbwema (1.74) and Sumbuya (1.72) (Table 3). The total land equivalent ratios across cropping system at all zones were greater than one (1) and on average ranged between 1.72 1.98. Furthermore, there were significant differences $(\mathrm{P}<0.05)$ in total land equivalent ratio among cropping system with cassava-soybean system recording the highest at all the zones. The total land equivalent ratio for the cropping systems across the three zones ranged between 1.92-2.14, 1.58-2.07 and 1.48-1.66 for the cassava-soybean, cassavagroundnut and cassava-cowpea systems respectively (Table 3).

Concerning spatial arrangement, partial land equivalent ratio for both cassava and the legumes were also above 0.5 across all three zones (Table 3). The total land equivalent ratio was on average higher for the $2 \mathrm{~m} \mathrm{x} 0.5 \mathrm{~m}$ spatial arrangement for cassava than the $1 \mathrm{~m} \times 1 \mathrm{~m}$ spatial arrangement among zones and cropping systems. The total land equivalent ratio across cropping systems and zones ranged between 1.66-1.99 and 1.55-1.72 for the $2 \mathrm{~m} \times 0.5 \mathrm{~m}$ and 1 $\mathrm{m} \times 1 \mathrm{~m}$ spatial arrangements respectively. Furthermore, the total land equivalent ratios were all above one (1) for both spatial arrangements and ranged between $1.63-1.89$ for all the cropping systems and zones (Table 3 ). At all zones, the cassava-soybean cropping system was observed to have recorded the highest land equivalent ratio. 
Table 3 Land equivalent ratio of cassava and component crops as influenced by cropping system and spatial arrangement of cassava

\begin{tabular}{|c|c|c|c|c|c|c|c|c|c|}
\hline \multicolumn{10}{|c|}{ Land equivalent ratio (LER) } \\
\hline & \multicolumn{9}{|c|}{ Agro-climatic zone } \\
\hline & \multicolumn{3}{|c|}{$\begin{array}{c}\text { Savannah woodland } \\
\text { (Makeni) }\end{array}$} & \multicolumn{3}{|c|}{ Rain forest (Segbwema) } & \multicolumn{3}{|c|}{$\begin{array}{l}\text { Transitional rain forest } \\
\text { (Sumbuya) }\end{array}$} \\
\hline Treatments & $\begin{array}{c}\text { LER } \\
\text { Cassava }\end{array}$ & $\begin{array}{c}\text { LER } \\
\text { Legume }\end{array}$ & Total & $\begin{array}{c}\text { LER } \\
\text { Cassava }\end{array}$ & $\begin{array}{c}\text { LER } \\
\text { Legume }\end{array}$ & Total & $\begin{array}{c}\text { LER } \\
\text { Cassava }\end{array}$ & $\begin{array}{c}\text { LER } \\
\text { Legume }\end{array}$ & Total \\
\hline \multicolumn{10}{|l|}{ Cropping system } \\
\hline $\begin{array}{l}\text { Cassava } \\
\text { groundnut }\end{array}$ & 1.16 & 0.91 & $2.07^{a}$ & 0.94 & 0.77 & $1.71^{\mathrm{b}}$ & 0.94 & 0.64 & $1.58^{b}$ \\
\hline Cassava-cowpea & 0.86 & 0.72 & $1.58^{\mathrm{b}}$ & 0.77 & 0.71 & $1.48^{\mathrm{c}}$ & 0.70 & 0.96 & $1.66^{\mathrm{ab}}$ \\
\hline Cassava-soybean & 1.26 & 0.88 & $2.14^{\mathrm{a}}$ & 1.14 & 0.90 & $2.04^{\mathrm{a}}$ & 1.21 & 0.71 & $1.92^{\mathrm{a}}$ \\
\hline Mean & & & $1.98^{\mathrm{a}}$ & & & $1.74^{\mathrm{a}}$ & & & $1.72^{\mathrm{a}}$ \\
\hline \multicolumn{10}{|c|}{ Spatial arrangement } \\
\hline \multicolumn{10}{|c|}{ Cassava-groundnut } \\
\hline $1 \mathrm{~m} \times 1 \mathrm{~m}$ & 0.76 & 0.70 & $1.46^{\mathrm{b}}$ & 0.80 & 0.63 & $1.43^{\mathrm{a}}$ & 0.73 & 0.70 & $1.43^{b}$ \\
\hline $2 \mathrm{~m} \times 0.5 \mathrm{~m}$ & 1.20 & 0.92 & $2.12^{\mathrm{a}}$ & 0.86 & 0.73 & $1.59 \mathrm{a}$ & 1.03 & 0.89 & $1.92^{\mathrm{a}}$ \\
\hline Mean & & & $1.84^{\mathrm{a}}$ & & & $1.51^{\mathrm{a}}$ & & & $1.68^{\mathrm{a}}$ \\
\hline \multicolumn{10}{|l|}{ Cassava -cowpea } \\
\hline $1 \mathrm{~m} \times 1 \mathrm{~m}$ & 0.75 & 0.52 & $1.27^{b}$ & 0.77 & 0.59 & $1.36^{\mathrm{b}}$ & 0.60 & 0.55 & $1.15^{\mathrm{a}}$ \\
\hline $2 \mathrm{~m} \times 0.5 \mathrm{~m}$ & 0.98 & 0.81 & $1.76^{\mathrm{a}}$ & 0.81 & 0.75 & $1.56^{\mathrm{a}}$ & 0.56 & 0.62 & $1.16^{\mathrm{a}}$ \\
\hline Mean & & & $1.52^{\mathrm{a}}$ & & & $1.46^{\mathrm{a}}$ & & & $1.50^{\mathrm{a}}$ \\
\hline \multicolumn{10}{|l|}{ Cassava-soybean } \\
\hline $1 \mathrm{~m} \times 1 \mathrm{~m}$ & 1.41 & 0.67 & $2.08^{\mathrm{b}}$ & 1.37 & 0.75 & $2.12^{\mathrm{a}}$ & 1.57 & 0.80 & $2.37^{\mathrm{a}}$ \\
\hline $2 \mathrm{~m} \times 0.5 \mathrm{~m}$ & 1.66 & 0.67 & $2.33^{\mathrm{a}}$ & 0.97 & 0.77 & $1.74^{\mathrm{b}}$ & 1.41 & 0.82 & $2.23^{\mathrm{a}}$ \\
\hline Mean & & & $2.21^{\mathrm{a}}$ & & & $1.93^{\mathrm{a}}$ & & & $2.30^{\mathrm{a}}$ \\
\hline
\end{tabular}

\subsubsection{Monetary advantage index (MAI)}

The monetary advantage index was highly significant $(\mathrm{P}<0.05)$ concerning cropping system with the cassava-soybean system recording the highest value followed by cassava-groundnut system whilst the cassava-cowpea system recorded the least across the three agro-climatic zones (Table 4). The mean monetary advantage index recorded with respect to the cassava-soybean cropping system across the three zones was $26.27 \%$ and $47.03 \%$ higher than cassava-groundnut and cassava-cowpea systems respectively (Table 4). In addition, there were significant differences with respect to zone with Segbwema (1,277.19) recording the highest followed by Makeni (979.93) and Sumbuya (952.61). The monetary advantage index recorded at Segbwema was $23.27 \%$ and $25.41 \%$ higher than Makeni and Sumbuya respectively (Table 4).

Relating to spatial arrangement, significant differences $(\mathrm{P}<0.05)$ were recorded concerning cassava-groundnut and cassava-cowpea systems with the $2 \mathrm{~m} \times 0.5 \mathrm{~m}$ spatial arrangement recording significantly higher values compared to the $1 \mathrm{~m} \times 1 \mathrm{~m}$ spatial arrangement across the three zones (Table 4). For the cassava-soybean system, significant differences $(\mathrm{P}<0.05)$ were also recorded at Segbwema and Sumbuya with the $1 \mathrm{~m} \times 1 \mathrm{~m}$ spatial arrangement recording the highest value compared to the $2 \mathrm{~m} \times 0.5 \mathrm{~m}$ spatial arrangement. However, at Makeni, the $2 \mathrm{~m} \times 0.5 \mathrm{~m}$ spatial 
arrangement recorded the highest monetary advantage index compared to the $1 \mathrm{~m} \times 1 \mathrm{~m}$ spatial arrangement (Table 4).

Table 4 Monetary advantage index of cassava and component crops as influence by cropping system and spatial arrangement of cassava

\begin{tabular}{|c|c|c|c|}
\hline \multicolumn{4}{|c|}{ Agro-climatic zone } \\
\hline \multirow[t]{2}{*}{ Treatments } & $\begin{array}{l}\text { Savannah woodland } \\
\text { (Makeni) }\end{array}$ & Rain forest (Segbwema) & $\begin{array}{c}\text { Transitional rain forest } \\
\text { (Sumbuya) }\end{array}$ \\
\hline & $\begin{array}{c}\text { Monetary Advantage Index } \\
\text { (MAI) }\end{array}$ & $\begin{array}{c}\text { Monetary Advantage Index } \\
\text { (MAI) }\end{array}$ & $\begin{array}{l}\text { Monetary Advantage Index } \\
\text { (MAI) }\end{array}$ \\
\hline \multicolumn{4}{|l|}{ Cropping system } \\
\hline $\begin{array}{l}\text { Cassava } \\
\text { groundnut }\end{array}$ & $1,087.00 \mathrm{~b}$ & $1,223.65 \mathrm{~b}$ & $815.75 b$ \\
\hline Cassava-cowpea & $628.01 \mathrm{c}$ & $1,001.17 \mathrm{c}$ & $625.59 \mathrm{c}$ \\
\hline Cassava-soybean & $1,224.8 \mathrm{a}$ & $1,606.74 \mathrm{a}$ & $1,416.48 \mathrm{a}$ \\
\hline Mean & $979.93 \mathrm{~b}$ & $1,277.19$ a & $952.61 \mathrm{~b}$ \\
\hline \multicolumn{4}{|c|}{ Spatial arrangement } \\
\hline \multicolumn{4}{|c|}{ Cassava-groundnut } \\
\hline $1 \mathrm{~m} \times 1 \mathrm{~m}$ & $476.58 \mathrm{~b}$ & $1,022.55 \mathrm{~b}$ & $528.48 \mathrm{~b}$ \\
\hline $2 \mathrm{~m} \times 0.5 \mathrm{~m}$ & $1,201.20 \mathrm{a}$ & $1,365.30 \mathrm{a}$ & $1,177.63 a$ \\
\hline Mean & $838.89 c$ & $1,193.93$ a & $885.056 \mathrm{~b}$ \\
\hline \multicolumn{4}{|l|}{ Cassava -cowpea } \\
\hline $1 \mathrm{~m} \times 1 \mathrm{~m}$ & $361.83 \mathrm{~b}$ & $871.03 \mathrm{~b}$ & $220.00 \mathrm{a}$ \\
\hline $2 \mathrm{~m} \times 0.5 \mathrm{~m}$ & $1,022.79 \mathrm{a}$ & $1,652.76 \mathrm{a}$ & $239.18 \mathrm{a}$ \\
\hline Mean & $692.37 \mathrm{~b}$ & $1,261.90 \mathrm{a}$ & $229.59 \mathrm{c}$ \\
\hline \multicolumn{4}{|l|}{ Cassava-soybean } \\
\hline $1 \mathrm{~m} \times 1 \mathrm{~m}$ & $1,476.95 \mathrm{~b}$ & $3,089.84 \mathrm{a}$ & $2,051.77 \mathrm{a}$ \\
\hline $2 \mathrm{~m} \times 0.5 \mathrm{~m}$ & $1,642.74 \mathrm{a}$ & $1,856.96 \mathrm{~b}$ & $1,815.77 \mathrm{~b}$ \\
\hline Mean & $1,559.84 \mathrm{c}$ & $2,473.40 \mathrm{a}$ & $1,933.77 \mathrm{~b}$ \\
\hline
\end{tabular}

\section{Discussions}

\subsection{Root and grain yield as influenced by cropping system and row arrangement}

The result from the study reveals significant differences in the root yield of cassava with respect to cropping system with the cassava-soybean cropping system recording yields that were higher than the sole cassava and the other cropping systems. The possible reason for this could be related probably to the low interspecific competition and the accompanied improvement in the soil structure that could be attributed to this system compared to the sole cassava and the other cropping systems. This result is in agreement with the findings of [16] who reported higher yield and yield related components of cassava in the intercropping systems with soybean compared to sole cassava. On the other hand, yield of the sole cassava was on average higher than the yields of the cassava-groundnut and the cassava-cowpea systems. This observation corroborate with the findings of [17] who reported higher yields in the sole cassava cropping system due to reduction in competition for growth resources, especially nitrogen. Another possible reason could be because the crop density in the sole crop was less and as such promotes more sunlight and other growth resources. 
The result further shows that the yield of all the legumes in the intercropping systems was lower than the sole legumes across the three zones. This could be due to interspecific competition between the cassava and the legumes and the shading effect by the tall cassava plant. This result conforms to the findings of [18]. These authors reported decrease in the yield of grain legumes in cassava-legumes intercropping systems in Nigeria. In contrast, studies carried out by [7] and [19] reported no significant effect in the yield of grain legumes in cassava-legume intercropping system. Furthermore, yield advantages in cassava and legumes were observed across cropping systems and spatial arrangements and were generally higher for the $2 \mathrm{~m} \mathrm{x} 0.5 \mathrm{~m}$ spatial arrangement compared to the $1 \mathrm{~m} \times 1 \mathrm{~m}$. The possible reason for this could be due to the weak interspecific competition in the $2 \mathrm{~m} \times 0.5 \mathrm{~m}$ ( $1 \mathrm{C}$ : $3 \mathrm{~L})$ spatial arrangement than that in $1 \mathrm{~m} \times 1 \mathrm{~m} \mathrm{(1} \mathrm{C:1} \mathrm{L)} \mathrm{spatial} \mathrm{arrangement,} \mathrm{which} \mathrm{led} \mathrm{to} \mathrm{the} \mathrm{improvement} \mathrm{of} \mathrm{both} \mathrm{root} \mathrm{and} \mathrm{grain}$ yield. This yield advantage could also be due to both temporal and complimentary effects of component crops such as better and total use of available resources as reported by [20]. This result is in contrast to that reported by [20] who reported no significant effect of spatial arrangement on mean cassava root yield. In addition, yields for both cassava and legumes were generally higher in Segbwema compared to the other agro-climatic zones.

Generally, despite the low individual yields of component crops under intercropping systems compared with sole cropping, the overall land productivity was greater under intercropping. Similar results have been reported by [21], [22] and [19] across diverse environments and cropping systems.

\subsection{Competitive and economic indices as influenced by cropping systems and spatial arrangement}

The growing of two or more crops together in the same field during a growing season may result in to either interspecific competition or facilitation between the component crops [23]. Therefore, the overall density of the mixtures and the relative proportions of component crops are paramount in determining the productivity of cassava-legume intercropping systems. Competition is one of the most important factors that influence significantly the rate of growth and yields of component crops in intercropping systems compared with sole cropping [9]. Thus, the assessment of competition between component crops and economic advantages of intercropping was conducted using indices such as land equivalent ratio (LER) and monetary advantage index (MAI).

Land equivalent ratio is an effective and widely used index for comparing intercropping systems due to different species growing on the same piece of land [24;25]. It reflects the extra advantage of intercropping systems over sole cropping systems.

The partial land equivalent ratios for both cassava and the legumes across the cropping systems were all above 0.5 indicating an advantage for intercropping both cassava and the legumes. In addition, on average the partial land equivalent ratio for cassava was greater than the legumes across all the cropping systems, which shows that cassava contributed more to the total yield compared to the legumes. In addition, it also shows that cassava was more competitive than the legumes and that it utilizes the nitrogen that was fixed by the legumes for better growth and yield. In addition, the total land equivalent ratio across cropping systems was all above one (1) and ranged from 1.72-1.92. This indicates an advantage of intercropping over sole cropping in terms of the use of environmental resources for plant growth. Furthermore, it shows that interspecific interaction or complementarity was greater than competition so that intercropping resulted into greater land use efficiency. It further indicates that $72 \%$ (0.72ha.) and 92\% (0.92ha) more land area will be require by the sole cropping system to produce the same yield as in the intercropping system. This result is similar to that reported by [25] in which he reported values of land equivalent ratio above one (1) in wheatlupine and barley intercropping system. In addition, values of land equivalent ratio greater than one (1) have been reported for sorghum-bottle gourd intercropping [26], cassava-legumes intercropping [27; 28; 6], and for cassavamaize-egusi-melon intercropping [29] systems.

The result further shows higher total land equivalent ratio for the cassava-soybean cropping system indicating that higher productivity per unit area was achieved in intercropping cassava with soybean than sole cropping and the other intercropping systems. This result conforms to the findings of [30]. These authors reported yield advantages in cassavasoybean mixtures compared to other cropping systems. The reason for the reported yield advantages of intercropping systems is because the component crops had different durations and growth patterns, hence, made major demands on resources at different times, which led to better temporal use of growth resources [31].

Concerning spatial arrangement, the total land equivalent ratio ranged from 1.46-2.30 between the two spatial arrangements, which show that the idea of intercropping cassava with cowpea, soybean and groundnut was highly productive in terms of environmental resource utilization relative to sole cropping. In addition, the higher land equivalent ratio reported with respect to the $2 \mathrm{~m} \times 0.5 \mathrm{~m} \mathrm{(1} \mathrm{C:} 3 \mathrm{~L})$ spatial arrangement of cassava indicates higher 
productivity under this arrangement resulting from the efficient utilization of environmental resources compared to the $1 \mathrm{~m} \times 1 \mathrm{~m}(1 \mathrm{C}: 1 \mathrm{~L})$ spatial arrangement. This finding also indicates that interspecific competition was reduced with increasing row distance between cassava and legumes and the competitive ability of intercropped legume was improved.

The monetary advantage index takes into account both economics and absolute yield advantage of intercropping systems over sole cropping [32; 25]. The study demonstrates that intercropping cassava with grain legumes significantly affects the monetary advantage index across cropping systems among the three zones. The monetary advantage indices were positive in all the cropping systems and were higher than one (1) which indicates that the intercropping systems were more economically feasible and profitable compared to the sole cropping. This result corroborate with the findings of [33] on maize-rape seed system. The higher monetary index recorded for the cassavasoybean system shows that the cropping system was more profitable compared to the other cropping system across the three agro-climatic zones. Furthermore, the higher monetary advantage index value recorded at Segbwema indicates high feasibility and profitability of the cropping systems in this zone. In addition, the higher monetary index value recorded across cropping systems and zones could be related to the higher land equivalent ratios and relative crowding coefficient values across cropping systems and zones. The above observation is in accordance with [10] who also related higher monetary advantage index with high land equivalent ratio and relative crowding coefficient values. These results also conforms with the findings of [34] who also reported a significant direct and positive relationship between higher values of land equivalent ratio, relative crowding coefficient and monetary advantage index. Furthermore, all intercropping combinations with respect to spatial arrangement recorded higher and positive monetary advantage index, which shows yield advantage of the intercropping systems. The higher monetary advantage index recorded for the $2 \mathrm{~m} \times 0.5 \mathrm{~m}$ spatial arrangement with respect to cassava-groundnut and cassava-cowpea systems shows that it has a higher economic advantage compared to the $1 \mathrm{~m} \mathrm{x} 1 \mathrm{~m}$ spatial arrangement. This result is in direct contrast to [35] and [36]. These authors reported positive and higher values in maize groundnut system with the $1 \mathrm{~m} \times 1 \mathrm{~m}$ spatial arrangement. However, for the cassava-soybean system, higher monetary advantage index values were recorded at Segbwema and Sumbuya for the $1 \mathrm{~m} \times 1 \mathrm{~m}$ spatial arrangement.

\section{Conclusion}

The study reveals that the yields of cassava and legumes were influenced by intercropping systems and spatial arrangement. The cassava-soybean cropping system was on average the most productive cropping system and the $2 \mathrm{~m}$ x $0.5 \mathrm{~m}$ spatial arrangement on average recorded the highest yield for both cassava and legumes. In generally, the study reported advantages of intercropping over sole cropping.

Result from the competitive and economic indices shows that cassava legume intercropping systems utilizes environmental sources more efficiently and was more profitable compared to the sole cropping. The total land equivalent ratio across cropping systems and spatial arrangement were all greater than one (1). The result obtained for the monetary advantage index shows that all intercropping systems were feasible and profitable.

\section{Compliance with ethical standards}

\section{Acknowledgments}

Many thanks to AFDB for funding the SARD-SC project and to all my supervisors for their support.

\section{Disclosure of conflict of interest}

Authors who include Augustine Mansaray, Abdul Babatunde Karim, Thomas Yormah and Abdul Rahman Conteh have declared that no competing interests exist.

\section{References}

[1] Hauggaard-Nielsen H, Gooding M, Ambus P, Corre- Hellou G, Crozat Y, Dahlmann C, Monti M. Pea-barley intercropping for efficient symbiotic N2 - fixation, soil N acquisition and use of other nutrients in European organic cropping systems. Field Crops Research. 2009; 113(1): 64-71.

[2] Chapagain T, Riseman A. Barley-pea intercropping: Effects on land productivity, carbon and nitrogen transformations. Field Crops Research. 2001; 166: 18- 2. 
[3] Mkamilo GS, Jeremiah S. Current status of cassava improvement programme in Tanzania. Afri. Crop Sci. Conference Proceedings. 2005; 7: 1311-1314.

[4] Okigbo BN, Greenland DJ. Intercropping Systems in the Tropical Africa. In: Stelly, M.S., Kral, D.M., Eisele, L.C. and Nanseef, J.H., Eds., Multiple Cropping, American Society of Agronomy (ASA), Madison, 1976. p. 63-101.

[5] MbahEU, Mouneke CO, Okpara DA. Effect of compound fertilizer on the yield and productivity of soybean and maize in soybean/maize intercrop in southern Nigeria. Tropical and Subtropical Agroecosystem. 2008; 7(2): 8795.

[6] Hidoto L, Loha G. Identification of suitable legumes in cassava(ManihotesculentaCrantz)-legumes intercropping. Afr. J. Agric. Res. 2013; 8: 2559-2562.

[7] Mutsaers HJW, Ezumah HC, Osiru DSO. Cassava-based intercropping: A review. Field Crops Res. 1993; 34(3): 431457.

[8] Osiru DSO, Hahn SK. Evaluation of cassava genotypes for intercropping systems, Root, Tuber and Plantain Improvement Program, Annual Report for 1987, IITA, Ibadan, Nigeria, 1998, 15-18.

[9] Caballero R, Goicoechea E, Hernaiz P. Forage yields and quality of common vetch and oat sown at varying seeding ratios and seeding rates of vetch. Field Crops Research. 1995; 41(2): 135-140.

[10] Dhima KV, Lithourgidis AS, Vasilakoglou IB, Dordas CA. Competition indices of common vetch and cereal intercrops in two seeding ratio. FieldCrops Res. 2007; 100: 249-256.

[11] Rezaei-Chianeh E, Nassab ADM, Shakiba MR, Ghassemi-Golezani K, Aharizad S,Shekari F. Intercropping of maize (ZeamaysL.)and faba bean (ViciafabaL.) at different plant population densities. .Afr. J. Agric. Res. 2011; 6:17861793.

[12] Willey R. Resource use in intercropping systems. Agricultural Water Management. 1990; 17(1-3): 215-231.

[13] Willey RW, Rao MR. A competitive ratio for quantifying competition between intercrops. Exp. Agric. 1980; 16: 117-125.

[14] Willey RW. Intercropping-its importance and research needs. Part 1. Competition and yield advantage. Field crop. Abstr. 1979; 32: 1-10.

[15] SAS Institute. The SAS system for windows. Release 9.4. Cary. NC. USA; 2014

[16] Kurtz LA. The yield and yield indices of cassava as affected by increasing planting densities of cowpea in a cassava- cowpea mixture. Crop Husbandry Research. 2006; 1: 90 -95.

[17] Njoku DN, Muoneke CO. Effect of cowpea planting density on growth, yield and productivity of component crops in cowpea-cassava intercropping system.J. Tropical Agriculture, Food, Environment and Extension. 2008; 7(2): 106-113.

[18] Ibeawuchi II, Ofoh MC, Nwufo MI, Obiefuna JC. Effects of landrace legumes-velvet bean, lima bean and African yam bean-on the performance of yam, cassava based crop mixtures. Journal of Plant Science. 2007; 2(4): 374386.

[19] Ennin SA, Dapaah HK. Legumes in sustainable maize and cassava cropping systems in Ghana. Agriculture and Food Science.Journal of Ghana. 2008; 7: 519- 540.

[20] Negash F, Mulualem T. Enhanced land use system through cassava-maize intercropping in south region of Ethiopia. Sky Journal of Agricultural Research. 2006; 3(10): 196 - 200.

[21] Dapaah HK, Asafu-Agyei JN, Ennin SA,Yamoah C. Yield stability of cassava, maize, soya bean and cowpea intercrops. The Journal of Agricultural Science. 2003; 140(01): 73-82.

[22] Okonji CJ, Okeleye KA, Olowe VIO, Ajayi EO. Potentials of intercropping rice (Orysa sativa L.) and cassava (ManihotesculentaCrantz.) of different morphotypes in the transition zone of South West Nigeria. International Journal of Agricultural Research. 2007; 2(5): 476-482.

[23] Zhang F,Li L. Using competitive and facilitative interactions in intercropping systems enhances crop productivity and nutrient-use efficiency. Plant and Soil. 2003;248: 305-312.

[24] Beets WC. Multiple Cropping and Tropical Farming Systems. Boulaer: Westview Press; 1982. 
[25] Yayeh B, Fetien A,Tadesse D. Effect of lupine (Lupinus spp.) intercropping and seed proportion on the yield and yield component of small cereals in North western Ethiopia. African Journal of Agricultural Research. 2014;9(30):2287-2297.

[26] Chimonyo VGP, Modi AT, Mabhaudhi T. Water use and productivity of a sorghum-cowpea-bottle gourd intercrop system. Agric Water Manage. 2016; 165:82-96.

[27] Islami T, Guritno B, Utomo WH. Performance of cassava (ManihotesculentaCrantz) based cropping systems and associated soil quality changes in the degraded tropical uplands of East Java, Indonesia. J.Trop.Agri. 2011; 49:3139.

[28] Mbah EU, OgidiE. Effect of soybean plant populations on yield and productivity of cassava and soybean grown in a cassava-based intercropping system. Trop. Subtrop. Agroecosyst. 2012; 15:241-248.

[29] Ijoyah MO, Bwala RI, Iheadindueme CA. Response of cassava,maize and egusi melon in a three crop intercropping system atMakurdi, Nigeria. Int. J .Dev. Sustain. 2012; 1:135-144.

[30] Mbah EU, Notindge DO, Keke CJ. Growth and yield of cassava-okra intercrop on an acid ultisol. Proceedings of the 43rd Annual conference of Agricultural Society of Nigeria (ASN). 20th - 23rd October, 2009. pp. 19 -23.

[31] Mbah EU, Muoneke CO. Effect of compound fertilizer on the yield and productivity of soybean and maize in soybean-maize intercrop in south eastern Nigeria. Trop. and subtrop. Agroecosystems. 2007; (7): 87-95.

[32] Tamado T, Mulatu E. Evaluation of sorghum, maize and common bean cropping systems in East Hararghe, Eastern Ethiopia. Ethiopian Journal of Agricultural Sciences. 2009; 17(2):33-45.

[33] Dutta H, Baroova SR, Rakhowa DJ. Feasibility and economic profitability of wheat (Triticumaestivum)-based intercropping systems under rainfed bconditions. Indian Journal of Agronomy. 1994; 39(3):448-450.

[34] Ghosh PK. Growth, yield, competition and economics of groundnut/cereal fodder intercropping systems in the semi-arid tropics of India. Field Crops Res. 2004; 88: 227-237.

[35] Khonde P, Tshiabukole K, Kankolongo M, Hauser S, Djamba M, Vumilia K, Nkongolo K. Evaluation of yield and competition indices for intercropped eight maize varieties, soybean and cowpea in the zone of savanna of SouthWest RD Congo. Open Access Library Journal. 2018; 5(1): 1-18.

[36] Kheroar S, Patra BC. Advantages of maize-legume intercropping systems. Journal of Agricultural Science and Technology. 2013; 3(10B): 733. 